\title{
Przekraczanie granic upoważnień ustawowych w praktyce prawodawczej rad gmin. Uwagi na tle ustawy o ochronie zabytków i opiece nad zabytkami ${ }^{1}$
}

\author{
Anna Michalak \\ Dr, Uniwersytet Łódzki, Wydział Prawa i Administracji, \\ Katedra Prawa Konstytucyjnego \\ http://dx.doi.org/10.18778/8088-114-3.09
}

Zachowanie dziedzictwa kulturowego, chociażby ze względu na jego znaczenie dla budowania tożsamości narodowej, stanowi jedno z podstawowych zadań państwa. Przesądza o tym treść art. 5 Konstytucji, zgodnie z którym „Rzeczpospolita Polska strzeże niepodległości i nienaruszalności swojego terytorium, zapewnia wolności i prawa człowieka i obywatela oraz bezpieczeństwo obywateli, strzeże dziedzictwa narodowego oraz zapewnia ochronę środowiska, kierując się zasadą zrównoważonego rozwoju”, a także art. 6 ust. 1 Konstytucji stanowiący, że „Rzeczpospolita Polska stwarza warunki upowszechniania i równego dostępu do dóbr kultury, będącej źródłem tożsamości narodu polskiego, jego trwania i rozwoju”. Konstytucja zobowiązuje zatem wszystkie organy administracji publicznej, w tym organy samorządu terytorialnego, do ochrony dziedzictwa kulturowego, a przede wszystkim jego materialnych wytworów, jakimi są zabytki. Dookreślenie tego konstytucyjnego obowiązku następuje na poziomie ustawodawstwa zwykłego. W konsekwencji ustawodawca przesądził, że opieka nad zabytkami należy do zadań własnych gminy, gdyż zgodnie z art. 7 ust. 1 pkt 9 ustawy z dnia 8 marca 1990 roku o samorządzie gminnym (tekst jednolity Dz. U z 2013 r., poz. 594 ze zm.; dalej: ustawa o samorządzie gminnym) zadania własne gminy obejmują także zadania w zakresie kultury, w tym bibliotek gminnych i innych instytucji kultury oraz ochrony zabytków i opieki nad zabytkami. Z kolei

1 Ustawa z dnia 23 lipca 2003 r. o ochronie zabytków i opiece nad zabytkami (tekst jednolity Dz.U. z 2014 r., poz. 1446, ze zm.; dalej: u.o.o.z.). Publikacja obejmuje stan prawny i orzecznictwo na dzień 30.09.2015 r. 
art. 4 ust. 7 ustawy z dnia 5 czerwca 1998 r. o samorządzie powiatowym (tekst jednolity Dz.U. z 2013 r., poz. 595, ze zm.; dalej: ustawa o samorządzie powiatowym) stanowi, że powiat wykonuje zadania o charakterze ponadgminnym, w tym m.in. w zakresie „kultury oraz ochrony zabytków i opieki nad zabytkami”. Zadania te mają charakter komplementarny i dotyczą tych zadań, których z określonych względów nie można realizować na szczeblu gminy. Natomiast samorząd województwa wykonuje zadania o charakterze wojewódzkim, w tym w szczególności na podstawie art. 14 ust. 3 ustawy z dnia 5 czerwca 1998 r. o samorządzie województwa, (tekst jednolity Dz.U. z 2015 r., poz. 1392; dalej: ustawa o samorządzie województwa) w zakresie „kultury oraz ochrony zabytków i opieki nad zabytkami”. Należy przy tym podkreślić, że wskazane przepisy ustaw samorządowych odnoszą się zarówno do ochrony zabytków, jak i opieki nad zabytkami. Rozróżnienie to ma doniosłe znaczenie, gdyż ochrona dotyczy władczej ingerencji, natomiast opieka polega na działalności faktycznej, stanowiąc obowiązek każdego właściciela i posiadacza zabytku, w tym jednostek samorządu terytorialnego ${ }^{2}$.

Konkretyzację kompetencji i obowiązków organów samorządu terytorialnego $\mathrm{w}$ powyższym zakresie stanowią postawienia ustawy $\mathrm{z}$ dnia 23 lipca 2003 r. o ochronie zabytków i opiece nad zabytkami. Analiza unormowań tego aktu normatywnego wskazuje, że to gmina jest jednostką samorządu terytorialnego, której powierzono szczególną rolę w ochronie dziedzictwa kulturowego. O ile bowiem jednostki samorządu terytorialnego każdego szczebla powinny uchwalić programy opieki nad zabytkami (art. 87 u.o.o.z.), realizując cele wytyczone na szczeblu centralnym w krajowym programie ochrony zabytków i opiece nad zabytkami (art. 87 u.o.o.z.) i mogą udzielać dotacji na prace restauratorskie, konserwatorskie lub roboty budowlane przy zabytku wpisanym do rejestru (art. 81 u.o.o.z.), to do wyłącznej kompetencji gminy należy m.in. prowadzenie ewidencji zabytków, która powinna stanowić kompletne i podstawowe źródło wiedzy na temat zasobu zabytkowego Polski (art. 22 ust. 4 u.o.o.z.) oraz prawo ustanowienia na jej terenie parku kulturowego ${ }^{3}$, a także

2 Szerzej na ten temat zob. K. Zalasińska, Ochrona dziedzictwa kulturowego jako zadanie własne jednostek samorzqdu terytorialnego, http://www.samorzad.lex.pl/ czytaj/-/artykul/ochrona-dziedzictwa-kulturowego-jako-zadanie-wlasne-jednostek-s amorzadu-terytorialnego, (dostęp 19.09.2015).

3 Aby chronić wyróżniające się krajobrazowo tereny wraz z położonymi na nich zabytkowymi nieruchomościami, gminy mogą tworzyć parki kulturowe. Decyzję w tej sprawie podejmuje rada gminy w formie uchwały, która powinna być zaopiniowana przez właściwego wojewódzkiego konserwatora zabytków. Uchwała rady powinna określać przede wszystkim: nazwę parku, jego granice, sposób ochrony, a także obowiązujące na jego terenie zakazy i ograniczenia. Te ostatnie mogą w szczególności dotyczyć: prowadzenia robót budowlanych oraz działalności przemysłowej, rolniczej, hodowlanej, handlowej lub usługowej; zmiany sposobu korzystania z zabytków nie- 
określenia zakresu ochrony konserwatorskiej w miejscowych planach zagospodarowania przestrzennego (art. 16-20 u.o.o.z.).

Gmina jest także organem egzekucyjnym decyzji wydawanych przez miejskich konserwatorów zabytków, a więc odpowiada za skuteczność m.in. decyzji nakazujących i zakazujących określonego działania, stanowiącego zagrożenie dla zabytku nieruchomego i jego otoczenia (art. 19 $\$ 2$ oraz art. $20 \$ 1$ pkt 2 ustawy z dnia 17 czerwca 1966 r. o postępowaniu egzekucyjnym w administracji, Dz.U. z 2014 r., poz. 1619, ze zm.).

Instrumentem umożliwiającym realizację wymienionych powyżej zadań jest przyznane organom stanowiącym jednostek samorządu terytorialnego prawo wydawania odpowiednich aktów prawa miejscowego, które zgodnie z art. 87 ust. 2 Konstytucji są źródłami powszechnie obowiązującego prawa na obszarze działania organów, które je ustanowiły. Powyższe oznacza, że na podstawie aktów prawa miejscowego organy władzy publicznej mogą wydać akty stosowania prawa (np. w postaci decyzji czy orzeczeń) w stosunku do jednostek i innych podmiotów, i akty te mogą stanowić podstawę przyznania uprawnienia bądź nałożenia obowiązku.

Zakres obowiązywania aktów prawa miejscowego jest ograniczony pod względem terytorialnym, ale także przedmiotowym, gdyż mogą one być wydawane przez organy samorządu terytorialnego i terenowe organy administracji rządowej niezespolonej jedynie na podstawie i w granicach upoważnień zawartych w ustawie (art. 94 Konstytucji). Realizację tych postanowień ustawy zasadniczej stanowią odpowiednie unormowania ustaw ustrojowych określających zasady funkcjonowania jednostek samorządu terytorialnego. W konsekwencji, na podstawie upoważnień ustawowych radzie gminie przysługuje prawo stanowienia aktów prawa miejscowego obowiązujących na obszarze gminy w formie uchwały (art. 40 i art. 41 ustawy z dnia 8 marca 1990 r. o samorządzie gminnym). Z kolei, na podstawie i w granicach upoważnień zawartych w ustawach,

ruchomych; umieszczania tablic, napisów, ogłoszeń reklamowych i innych znaków niezwiązanych z ochroną parku kulturowego (z wyjątkiem znaków drogowych oraz znaków związanych z ochroną porządku i bezpieczeństwa publicznego); składowania lub magazynowania odpadów.

Dla obszarów, na których utworzony został park kultury, gmina ma obowiązek opracować i uchwalić miejscowy plan zagospodarowania przestrzennego. 0 ile zadaniem rady jest utworzenie parku, a także powołanie do życia jednostki organizacyjnej, której zadaniem będzie zarządzanie tym terenem, o tyle do wójta należy stworzenie planu ochrony parku kulturowego. Plan ten organ wykonawczy gminy sporządza w porozumieniu z właściwym miejscowo wojewódzkim konserwatorem zabytków. Do wejścia w życie planu ochrony konieczne jest również jego zatwierdzenie przez radę gminy, która w tej sprawie podejmuje stosowną uchwałę (por. art. 16 u.o.o.z.).

4 Prawo administracyjne: pojęcia, instytucje, zasady w teorii i orzecznictwie, red. Z. Duniewska, B. Jaworska-Dębska, R. Michalska-Badziak, Warszawa 2009, s. 220. 
rada powiatu stanowi akty prawa miejscowego obowiązujące na obszarze powiatu (art. 40 ustawy z dnia 5 czerwca 1998 r. o samorządzie powiatowym). Akty te rada powiatu stanowi w formie uchwały, jeżeli ustawa upoważniająca do wydania aktu nie stanowi inaczej (art. 41 ustawy z dnia 5 czerwca 1998 r. o samorządzie powiatowym). Natomiast, na podstawie ustawy z dnia 5 czerwca 1998 r. o samorządzie województwa oraz na podstawie upoważnień udzielonych w innych ustawach i w ich granicach sejmik województwa stanowi akty prawa miejscowego obowiązujące na obszarze województwa lub jego części (art. 89 tej ustawy).

Zgodzić należy się z tezą, że mimo przyznanej samorządowi terytorialnemu, a uzasadnionej ustrojowo, dużej samodzielności w stanowieniu prawa miejscowego, wola mieszkańców nie jest źródłem wyłącznym ani nawet podstawowym władzy samorządowej. Źródłem tej władzy i odrębności samorządu terytorialnego jest bowiem pozytywne unormowanie prawne, czyli normy Konstytucji i ustaw ${ }^{5}$. Wynikające z art. 163 Konstytucji domniemanie kompetencji samorządu terytorialnego do wykonywania zadań publicznych może być obalone przez regulację ustawową przyznającą kompetencję do wykonywania zadań publicznych w danej dziedzinie administracji rządowej. Samorząd wykonuje samodzielnie zadania publiczne, ale na podstawie ustaw i w ramach ustaw. Z tego też względu prawo miejscowe samorządu terytorialnego nie może być rozpatrywane wyłącznie jako wyraz woli mieszkańców wspólnoty, jest ono bowiem zdeterminowane także przez ustawodawstwo. Przyjęty w Polsce model ustrojowy wymusza traktowanie prawotwórczej funkcji samorządu terytorialnego jako funkcji pochodnej, spełnianej tylko na podstawie upoważnień ustawowych. Samorząd terytorialny korzysta zatem jedynie $\mathrm{z}$ tych praw, które zostały mu przyznane mu w ustawach ${ }^{6} \mathrm{i}$ w określonych tam granicach.

W konsekwencji wykonywanie uprawnień prawotwórczych jednostek samorządu terytorialnego, podobnie jak realizacja pozostałych kompetencji, podlega nadzorowi. Nadzór ten ograniczony został jedynie do oceny legalności działalności samorządu. Oznacza to, że organ nadzoru może badać działalność jednostki samorządu tylko pod względem jej zgodności z prawem powszechnie obowiązującym (art. 171 ust. 1 Kon-

5 Por. uchwałę TK z dnia 27 września 1994 r., W 10/93, OTK 1994, nr 2, poz. 46, w której Trybunał podkreśla, że źródłem legitymacji samorządu jest prawo stanowione przez państwo, co powoduje, że samorząd nie nabiera przymiotu władzy suwerennej; taki sam pogląd wyraża Trybunał Konstytucyjny także w wyrokach z dnia 26 maja 1998 r., K 17/98, OTK 1998, nr 4, poz. 48 oraz z dnia 3 listopada 1999 r., K 13/99, OTK 1997, nr 7, poz. 155).

6 K. Bandarzewski, D. Dąbek, P. Dobosz et al., Komentarz do art. 89 ustawy o samorządzie województwa, teza 8, [w:] Komentarz do ustawy o samorządzie województwa, red. P.A. Chmielnicki, Warszawa 2005. 
stytucji). Organy nadzoru mogą zatem wkraczać w działalność samorządu tylko wówczas, gdy zostanie naruszone prawo, nie są zaś upoważnione do oceny celowości, rzetelności i gospodarności działań podejmowanych przez samorząd ${ }^{7}$. Konstytucyjne kryterium legalności w zakresie nadzoru nad działalnością jednostek samorządu terytorialnego określone jest także w samorządowych ustawach ustrojowych (art. 85 ustawy z dnia 8 marca 1990 r. o samorządzie gminnym, art. 77 ustawy z dnia 5 czerwca 1998 r. o samorządzie powiatowym, art. 79 ustawy z dnia 5 czerwca 1998 r. o samorządzie województwa).

Organami nadzoru nad samorządem terytorialnym są Prezes Rady Ministrów i wojewodowie, a w zakresie spraw finansowych - regionalne izby obrachunkowe (art. 171 ust. 2 Konstytucji) ${ }^{8}$. Ustawa zasadnicza w sposób enumeratywny wskazuje podmioty wyposażone w kompetencje nadzorcze wobec samorządu, co niewątpliwie wzmacnia jego niezależność. Regulacje konstytucyjne wskazujące podmioty nadzoru nad samorządem terytorialnym zostały powtórzone w ustawach ustrojowych. Wszystkie trzy ustawy ustrojowe potwierdzają także, że organy nadzoru mogą wkraczać w działalność jednostki samorządu tylko w przypadkach określonych ustawami9.

Prezes Rady Ministrów, jako naczelny organ administracji publicznej, sprawuje nadzór nad wszystkimi jednostkami samorządu terytorialnego w kraju (art. 148 pkt 6 Konstytucji). Niemniej z punktu widzenia dalszych rozważań dotyczących uprawnień prawodawczych rady gminy, najistotniejsze są uprawnienia nadzorcze organów właściwych miejscowo tj. wojewodów oraz regionalnych izb rachunkowych.

W świetle postanowień samorządowych ustaw ustrojowych to wojewoda jest organem nadzoru ogólnego. Na jego rzecz przemawia bowiem domniemanie kompetencji nadzorczych. Jest on zatem właściwy we wszystkich sprawach, które nie należą do Prezesa Rady Ministrów i do regionalnej izby obrachunkowej. Wojewodowie sprawują nadzór ogólny, podczas gdy izby sprawują nadzór wyspecjalizowany. Co do zasady nadzór nad samorządem terytorialnym powinien pozostawać w gestii

7 M. Masternak-Kubiak, Komentarz do art.171 Konstytucji Rzeczypospolitej Polskiej, teza 2, [w:] Konstytucja Rzeczypospolitej Polskiej. Komentarz, red. Haczkowska M., Warszawa 2014.

8 Organy wskazane w tym przepisie Konstytucji nie są jedynymi podmiotami uczestniczącymi w nadzorze nad działalnością gminną. W sprawowaniu tego nadzoru biorą także udział: Sejm (art. 171 ust. 3 Konstytucji) oraz inne organy wskazane w ustawach ustrojowych, np. minister właściwy do spraw administracji publicznej (art. 96 ust. 1 i 2, art. 97 ust. 1 i 3, art. 98a ust. 2 ustawy o samorządzie gminnym), minister właściwy do spraw Skarbu Państwa (art. 49 ustawy o samorządzie województwa), organy gminy (art. 35 ust. 3 pkt 5 ustawy o samorządzie gminnym).

9 Art. 87 ustawy o samorządzie gminnym, art. 76 ust. 2 ustawy o samorządzie powiatu, art. 78 ust. 2 ustawy o samorządzie województwa. 
wojewody, natomiast działalność izb obrachunkowych powinna się ograniczyć tylko do spraw finansowych. Należy zatem przyjąć, że właściwość rzeczowa wojewody, będącego organem nadzoru o właściwości generalnej, doznaje ograniczenia tylko w odniesieniu do spraw wymienionych w art. 11 ust. 1 ustawy z dnia 7 października 1992 r. o regionalnych izbach obrachunkowych (tekst jednolity Dz.U. z 2012 r., poz. 1113, ze zm., dalej: ustawa o RIO ${ }^{10}$.

Nadzór regionalnych izb obrachunkowych nad działalnością jednostek samorządu terytorialnego jest ściśle ukierunkowany i obejmuje wyłącznie sprawy finansowe. Regionalna izba obrachunkowa jest państwowym organem nadzoru (instytucją nadzoru) nad działalnością jednostek samorządu terytorialnego $\mathrm{w}$ zakresie spraw finansowych oraz kontroli gospodarki finansowej i zamówień publicznych tych jednostek (art. 1 ustawy o RIO). Zgodnie $\mathrm{z}$ art. 18 ust. 1 pkt 1 ustawy o RIO do wyłącznej właściwości kolegium izby należy ustalanie budżetu jednostki samorządu terytorialnego oraz orzekanie o nieważności uchwał i zarządzeń, o których mowa w art. 11 ust. 1 ustawy o regionalnych izbach obrachunkowych.

W orzecznictwie i piśmiennictwie konstytucyjnym pojęcie „sprawy finansowe" - określające zakres nadzoru regionalnej izby obrachunkowej - zostało uznane zasadniczo za tożsame z określonym $\mathrm{w}$ art. 11 ust. 1 ustawy o RIO zakresem przedmiotowym uchwał i zarządzeń organów samorządu w sprawach: procedury uchwalania budżetu i jego zmian; zaciągania zobowiązań wpływających na wysokość długu publicznego jednostki samorządu terytorialnego oraz udzielania pożyczek; zasad i zakresu przyznawania dotacji z budżetu jednostki samorządu terytorialnego; podatków i opłat lokalnych, do których mają zastosowanie przepisy ustawy - Ordynacja podatkowa; absolutorium; wieloletniej prognozy finansowej i jej zmian. Właściwość izb została zatem określona w drodze enumeracji pozytywnej, wytyczającej granicę materii nadzorczych pomiędzy kognicją wojewodów i izb ${ }^{11}$.

W świetle powyższych rozważań istotne znaczenie dla określenia i delimitacji zakresu kompetencji nadzorczych zarówno wojewody, jak i regionalnych izb obrachunkowych ma normatywne pojęcie: „sprawy finansowe". Pojęcie to nie ma definicji legalnej. Naczelny Sąd Administracyjny wyraża pogląd, że określenie „w sprawie” oznacza wszystkie kwestie powiązane rzeczowo z zasadniczym, określonym hasłowo zagadnieniem, w tym przypadku z finansami. Sąd ten stanął na stanowisku, że skoro nie ma legalnej definicji pojęcia: „sprawy finansowe”, która jednoznacznie

10 Por. także H. Izdebski, Samorząd terytorialny. Podstawy ustroju i działalności, Warszawa 2011, s. 432.

11 Por. Z. Kmieciak, M. Stahl, Akty nadzoru nad działalnością samorządu terytorialnego, „Samorząd Terytorialny” 2001, nr 1-2, s. 105 i nast. 
ograniczyłaby katalog spraw poddanych nadzorowi regionalnych izb obrachunkowych wyłącznie do tych wymienionych w art. 11 ust. 1 ustawy o RIO, to nie można tego pojęcia, a co za tym idzie - kompetencji nadzorczych regionalnych izb obrachunkowych - zawężać przez domniemanie kompetencji wojewody ${ }^{12}$.

Analiza rozstrzygnięć nadzorczych wydawanych w związku ze stosowaniem przepisów u.o.o.z. przez organy jednostek samorządu terytorialnego (zwłaszcza na szczeblu gminnym) prowadzi do wniosku, że największe trudności i problemy praktyczne rysują się na tle dwóch unormowań tej ustawy.

Po pierwsze, są one związane z przekraczaniem kompetencji do modyfikowania zakresu współdziałania organów w postępowaniu administracyjnym przy wydawaniu decyzji administracyjnych. Problemy praktyczne w tym zakresie pojawiają się na tle art. 36 u.o.o.z. ${ }^{13}$, który określa w sposób enumeratywny wszystkie działania, dla podjęcia których wymagane jest uprzednie uzyskanie pozwolenia wojewódzkiego konserwatora zabytków. Powyższe oznacza, że tylko w sytuacjach określonych $\mathrm{w}$ tym przepisie, występuje obowiązek uzyskania takiego pozwolenia i brak jest możliwości rozszerzenia obowiązku uzyskania pozwolenia wojewódzkiego konserwatora zabytków w akcie prawa miejscowego. Niemniej, jak wynika z orzecznictwa, organy stanowiące jednostek samorządu terytorialnego podejmują działania prawodawcze mające na celu rozszerzenie tego katalogu, lub dookreślenie pojęć w nim wskazanych. Przekroczenie upoważnienia ustawowego w tym zakresie związane jest przede wszystkim z podejmowaniem przez gminy uchwał w trybie art. 15 ust. 2 pkt 4 ustawy z dnia 27 marca 2003 r. o planowaniu i zagospodaro-

12 Wyrok z dnia 29 listopada 2007 r., sygn. akt II GSK 261/2007, wyrok NSA z dnia 15 października 2013 r., sygn. akt II OSK 1706/2013.

13 Zgodnie z art. 36 ust. 1 u.o.o.z. pozwolenia wojewódzkiego konserwatora zabytków wymaga: prowadzenie prac konserwatorskich, restauratorskich lub robót budowlanych przy zabytku wpisanym do rejestru; wykonywanie robót budowlanych w otoczeniu zabytku; prowadzenie badań konserwatorskich zabytku wpisanego do rejestru; prowadzenie badań architektonicznych zabytku wpisanego do rejestru; prowadzenie badań archeologicznych; przemieszczanie zabytku nieruchomego wpisanego do rejestru; trwałe przeniesienie zabytku ruchomego wpisanego do rejestru, z naruszeniem ustalonego tradycją wystroju wnętrza, w którym zabytek ten się znajduje; dokonywanie podziału zabytku nieruchomego wpisanego do rejestru; zmiana przeznaczenia zabytku wpisanego do rejestru lub sposobu korzystania z tego zabytku; umieszczanie na zabytku wpisanym do rejestru: urządzeń technicznych, tablic reklamowych lub urządzeń reklamowych oraz napisów; podejmowanie innych działań, które mogłyby prowadzić do naruszenia substancji lub zmiany wyglądu zabytku wpisanego do rejestru; poszukiwanie ukrytych lub porzuconych zabytków ruchomych, w tym zabytków archeologicznych, przy użyciu wszelkiego rodzaju urządzeń elektronicznych i technicznych oraz sprzętu do nurkowania. 
waniu przestrzennym (Dz.U. Nr 80, poz. 717; ze zm.), tj. uchwaleniem planu zagospodarowania przestrzennego ${ }^{14}$. Przekroczenie delegacji ustawowej w praktyce organów stanowiących rad gminy polegało m.in. na:

- wprowadzeniu nakazu opiniowania wszelkich prac remontowo-budowlanych mających wpływ na wygląd zewnętrzny obiektów z wojewódzkim konserwatorem zabytków oraz nakazu wykonywania prac ziemnych po uzgodnieniu i za pozwoleniem tego konserwatora zabytków w miejscowym planie zagospodarowania przestrzennego terenu (zob. Rozstrzygnięcie nadzorcze Wojewody Kujawsko-Pomorskiego z dnia 17 marca 2014 r., znak: 15/14);

- wyznaczeniu strefy obserwacji archeologicznej dla całego obszaru objętego planem zagospodarowania przestrzennego i wprowadzenia obowiązku prowadzenia wszelkich prac ziemnych o charakterze inwestycyjnym pod nadzorem archeologicznym, po uprzednim uzyskaniu pisemnej decyzji Wojewódzkiego Konserwatora Zabytków (zob. Rozstrzygnięcie nadzorcze Wojewody Dolnośląskiego z dnia 27 lipca 2012 r., znak: NK-N5.4131.652.2012.GD1);

- wprowadzeniu obowiązku uzyskania pozwolenia wojewódzkiego konserwatora zabytków na prowadzenie ziemnych robót budowlanych na terenie zabytkowym w trybie prac konserwatorskich poprzez przeprowadzenie ratowniczych badań archeologicznych metodą wykopaliskową przez uprawnionego archeologa przed uzyskaniem pozwolenia na budowę, a dla robót niewymagających pozwolenia na budowę - przed realizacją inwestycji tj. przed uzyskaniem zaświadczenia potwierdzającego akceptację przyjęcia zgłoszenia wykonywania robót budowlanych (zob. Rozstrzygnięcie nadzorcze Wojewody Dolnośląskiego z dnia 14 czerwca 2012 r., znak: NK-N13.4131.388.2012.JT1).

- zawarciu w uchwale w sprawie miejscowego planu zagospodarowania przestrzennego postanowienia, że decyzja o rozbiórce budynku ujętego w gminnej ewidencji zabytków może być uzależniona od wcześniejszego wykonania karty ewidencyjnej zgodnie z instrukcją Krajowego Ośrodka Badań i Dokumentacji Zabytków w Warszawie oraz uzależnienie jej od pozytywnej opinii ekspertyzy budowlanej opracowanej przez rzeczoznawcę budowlanego oraz od potrzeby odbudowy budynku (zob. Rozstrzygnięcie nadzorcze Wojewody Dolnośląskiego z dnia 29 lipca 2011 r., znak: NK-N.4131.713.2011.JT1-1);

14 Charakter prawny uchwały rady gminy o utworzeniu parku kulturowego, jako aktu prawa miejscowego, nie budzi przy tym wątpliwości (zob. M. Rymer, Rola jednostek samorzqdu terytorialnego w systemie ochrony zabytków - analiza wybranych problemów, [w:] Ochrona zabytków militarnych Helu, red. Gryszczyńska A., Konieczna B., Toruń 2006, s. 30). 
- ustaleniu przez radę miejską zasad i warunków umieszczania szyldów i reklam na terenie zabytkowego śródmieścia, które określają jedyne dopuszczalne formy montażu reklam i szyldów (zob. Rozstrzygnięcie nadzorcze Wojewody Podlaskiego z dnia 29 kwietnia 2008 r., znak: NK.II.DJ.0911-94/08).

Problemy rodzi także stosowanie art. $71^{15} \mathrm{w}$ związku $\mathrm{z}$ art. $81^{16}$ u.o.o.z. Przepisy te określają zasady finansowania prac konserwatorskich, restauratorskich i robót budowlanych przy zabytku, w tym zasady przyznawania dotacji w tym zakresie.

Zgodnie z przepisami u.o.o.z. właściciele zabytków - osoby fizyczne lub jednostki organizacyjne posiadające tytuł prawny do zabytku wynikający z prawa własności, użytkowania wieczystego, trwałego zarządu, ograniczonego prawa rzeczowego albo stosunku zobowiązaniowego - na mocy tej ustawy zostali zobowiązani do finansowania prac konserwatorskich, restauratorskich i robót budowlanych. Działania te wchodzą bowiem w zakres sprawowanej przez właścicieli opieki nad zabytkiem, polegającej w szczególności na zabezpieczeniu i utrzymaniu zabytku wraz z otoczeniem w jak najlepszym stanie. Jednostki samorządu terytorialnego, w których posiadaniu znajdują się zabytki, mogą otrzymywać - tak jak każdy inny posiadacz takiego obiektu - dotacje $z$ budżetu centralnego na dofinansowanie prac konserwatorskich, restauratorskich lub robót budowlanych przy tym zabytku. Dotacji takiej udziela albo minister właściwy do spraw kultury, albo wojewódzki konserwator zabytków. Ponadto, jak wynika z przepisów u.o.o.z., gminy, a także powiaty i województwa samorządowe, mogą nie tylko otrzymywać dotacje na opiekę nad zabytkami, ale również wspierać finansowo prace przy zabytkach.

W konsekwencji problematyczne staje się ustalenie, kiedy jednostka samorządu terytorialnego może traktować finansowanie prac przy zabytku jako realizację zadań własnych.

15 Zgodnie z art. 71 ust. 1 u.o.o.z. w zakresie sprawowania opieki nad zabytkami osoba fizyczna lub jednostka organizacyjna posiadająca tytuł prawny do zabytku wynikający z prawa własności, użytkowania wieczystego, trwałego zarządu, ograniczonego prawa rzeczowego albo stosunku zobowiązaniowego finansuje prowadzenie prac konserwatorskich, restauratorskich i robót budowlanych przy tym zabytku. Jednocześnie sprawowanie opieki nad zabytkami, w tym finansowanie prac konserwatorskich, restauratorskich i robót budowlanych przy zabytku, do którego tytut prawny, określony wyżej, posiada jednostka samorządu terytorialnego, jest zadaniem własnym tej jednostki (art. 71 ust. 2 u.o.o.z.).

16 Artykuł 81 ust. 1 u.o.o.z. stanowi, że w trybie określonym odrębnymi przepisami dotacja na prace konserwatorskie, restauratorskie lub roboty budowlane przy zabytku wpisanym do rejestru może być udzielona przez organ stanowiący gminy, powiatu lub samorządu województwa, na zasadach określonych w podjętej przez ten organ uchwale. Dotacja ta może być udzielona w wysokości do 100\% nakładów koniecznych na wykonanie przez wnioskodawcę prac konserwatorskich, restauratorskich lub robót budowlanych przy zabytku wpisanym do rejestru (art. 81 ust. 2 u.o.o.z.). 
Zadaniem gminy jest opieka nad wszystkimi zabytkami znajdującymi się na terenie gminy, nie tylko wpisanymi do rejestru zabytków. Przepisy prawa nie stanowią o dowolności wydatkowania środków publicznych na cele niezwiązane $\mathrm{z}$ realizacją zadań własnych, tym bardziej przysparzających korzyści materialnych jednostkom spoza sektora finansów publicznych (zob. uchwała RIO w Szczecinie z dnia 17 listopada 2010 r., znak: XXVII/157/S/2010). Ustawa przewiduje bowiem różne mechanizmy finansowania zabytków znajdujących się na terenie jednostki samorządu terytorialnego. Z innych środków będzie finansowana opieka nad zabytkami stanowiącymi własność jednostek samorządu terytorialnego (jako zadanie własnym), z innych - finansowanie opieki nad zabytkami rejestrowymi niestanowiącymi własności jednostki samorządu terytorialnego.

Do jednostek samorządu terytorialnego jako prawnych dysponentów zabytków znajduje zastosowanie zarówno ust. 1, jak i ust. 2 art. 71 u.o.o.z., z tym, że pierwszy z tych przepisów nakłada na nie w ogólności obowiązek finansowania prac i robót przy przypisanych im formalnie zabytkach, zaś ust. 2 stwierdza, iż obowiązek w tym zakresie jest zadaniem własnym tych jednostek, czyli nie może być przez nie traktowany jako zadanie zlecone do realizacji przez administrację rządową (por. wyrok WSA z dnia 31 maja 2010 r., sygn. akt I SA/Gd 395/10, LEX nr 786766, wyrok WSA w Gdańsku z dnia 20 maja 2010 r., sygn. akt I SA/Gd 371/10, LEX nr 673156). Wynika $z$ tego, że dla podmiotowego zakresu obowiązku finansowania opieki nad zabytkami, zgodnie $\mathrm{z}$ art. 71 u.o.o.z. nie ma znaczenia status prawny dysponenta zabytku, tylko to, czy przysługuje mu do niego określony tytuł prawny. Nie ma przy tym znaczenia, czy jest to tytuł prawny w postaci prawa rzeczowego, takiego jak prawo własności albo ograniczone prawo rzeczowe, np. użytkowanie, czy też w postaci prawa obligacyjnego (umownego), np. wynikającego z umowy dzierżawy (zob. wyrok WSA w Gdańsku z dnia 20 maja 2010 r., sygn. akt I SA/Gd 370/10, LEX nr 673155). Może wynikać również z umowy użyczenia zawartej między gminą a parafią (zob. wyrok WSA w Gdańsku z dnia 26 kwietnia 2010 r., sygn. akt I SA/Gd 249/10). A contrario sprawowanie opieki nad zabytkami, w tym finansowanie prac konserwatorskich, restauratorskich i robót budowlanych przy zabytku stanowiącym własność Parafii Rzymskokatolickiej nie jest zadaniem własnym gminy. Rada gminy nie jest zatem uprawniona do zaciągania zobowiązań powyżej planowanych środków w budżecie gminy na dofinansowanie prac remontowo-konserwatorskich dachu na zabytkowym kościele prowadzonych przez Parafię Rzymskokatolicką (zob. uchwała RIO w Rzeszowie z dnia 5 maja 2009 r., znak: X/2936/2009).

W konsekwencji dopiero ustalenie, iż jednostka samorządu terytorialnego jest stroną skutecznie zawartej i ważnej umowy, której przedmiotem jest określony zabytek, w świetle art. 71 ust. 2 u.o.o.z., daje jej nie tylko 
możliwość, ale obliguje do sprawowania opieki nad zabytkiem, również poprzez finansowanie prac konserwatorskich, restauratorskich i robót budowlanych, w ramach zadań własnych jednostki samorządu terytorialnego, a bez znaczenia jest, czy wiążąca jednostkę samorządu umowa jest umową nazwaną czy też nienazwaną, jednostronnie czy też dwustronnie zobowiązującą, realną czy konsensualną itp. (zob. wyrok NSA z dnia 29 września 2011 r., sygn. akt II GSK 934/10, LEX nr 1068902). Istotne jest wyłącznie to, aby treść stosunku zobowiązującego do sprawowania opieki nad obiektem była zgodna $z$ art. 71 u.o.o.z. (zob. wyrok NSA z dnia 22 września 2011 r., sygn. akt II GSK 907/10, LEX nr 964516, wyrok NSA z dnia 1 czerwca 2010 r., sygn. akt II GSK 43/10, LEX nr 596813).

$\mathrm{Z}$ kolei art. 81 ust. 1 u.o.o.z. stanowi podstawę prawną do podjęcia dwóch uchwał zastrzeżonych do kompetencji rady gminy, tj. uchwały określającej zasady udzielania dotacji oraz następczej w stosunku do niej uchwały o przyznaniu dotacji. Uchwała w sprawie zasad udzielania dotacji jest aktem prawa miejscowego, natomiast uchwała rady gminy w sprawie przyznania dotacji konkretnemu podmiotowi (beneficjentowi) jest aktem indywidualnym. Ustawodawca ustalił krąg podmiotów, którym dotacja może być przyznana, a także rodzaje nakładów na prace konserwatorskie, restauratorskie i roboty budowlane przy zabytku wpisanym do rejestru, które mogą uzyskać wsparcie finansowe w tej formie.

Dlatego rada gminy nie może ograniczyć kręgu podmiotów, które mogą ubiegać się o dotację. O taką dotację może bowiem ubiegać się każdy podmiot zobligowany do finansowania prowadzenia prac konserwatorskich, restauratorskich i robót budowlanych przy zabytku, mający tytuł prawny do zabytku. Krąg tych podmiotów określa art. 71 ust. 1 u.o.o.z. (zob. uchwała RIO w Gdańsku z dnia 2 października 2014 r., znak: 199/G127/D/14, uchwała RIO w Rzeszowie z dnia 2 czerwca 2009 r., znak: XII/3803/09). Przekroczeniem delegacji ustawowej będzie zatem ograniczenie w uchwale rady gminy kręgu podmiotów - wnioskodawców mogących ubiegać się o udzielenie dotacji z budżetu gminy na dofinansowanie prac restauratorskich, konserwatorskich lub robót budowlanych przy zabytku wpisanym do rejestru zabytków wyłącznie do osób fizycznych lub jednostek organizacyjnych będących właścicielami lub posiadaczami zabytku wpisanego do rejestru albo posiadających taki zabytek w trwałym zarządzie (zob. uchwała RIO w Rzeszowie z dnia 3 kwietnia 2012 r., znak: VII/1473/2012), albo wykluczenie osób fizycznych i jednostek organizacyjnych będących przedsiębiorcami lub podmiotami niezaliczanymi do sektora finansów publicznych z kręgu podmiotów uprawnionych do ubiegania się o finansowanie $\mathrm{z}$ budżetu gminy umożliwiające trwałe zachowanie zabytków oraz ich zagospodarowanie i utrzymanie (zob. uchwała RIO w Kielcach z dnia 4 stycznia 2012 r., znak: 1/2012, uchwała RIO w Kielcach z dnia 3 sierpnia 2011 r., znak: 64/2011, uchwała RIO w Zielonej Górze z dnia 27 listopada 
2009 r., znak: 225/2009). Postanowienia takie kolidują także z zasadą równości w zakresie ubiegania się o środki publiczne na finansowanie zadań, wynikającą $\mathrm{z}$ art. 43 u.f.p. ${ }^{17}$ (zob. uchwała RIO we Wrocławiu z dnia 27 października 2010 r., znak: 81/2010). Co do zasady, wsparcie podmiotów posiadających tytuł prawny do zabytku w celu dofinansowania prac przy zabytku nie może być zatem uzależnione od tego, czy podmioty te zaliczane są do sektora finansów publicznych, czy nie, ani także od tego, czy prowadzą działalność w celu osiągnięcia zysku, czy nie. Istotne jest tylko, aby dotacja przeznaczona została na cele właściwe jej udzieleniu (zob. uchwała RIO w Poznaniu z dnia 12 października 2011 r., znak: 20/1652/2011, oraz z dnia 12 stycznia 2011r., znak:1/30/2011).

Artykuł 81 ust. 1 u.o.o.z. daje organowi stanowiącemu jednostki samorządu terytorialnego prawo określania zasad udzielania dotacji, nie pozwala zaś na regulowanie kwestii dotyczących kontroli wykorzystania dotacji i wykonania zadania przez podmiot dotowany. W zakresie trybu udzielenia dotacji z budżetu gminy na prace konserwatorskie, restauratorskie lub roboty budowlane przy zabytku wpisanym do rejestru zastosowanie będą miały przepisy ustawy u.f.p., a w zakresie rodzaju prac, które mogą być finansowane $\mathrm{z}$ dotacji - art. 77 u.o.o.z. (zob. uchwała RIO w Łodzi z dnia 29 czerwca 2010 r., znak: 23/105/2010).

Natomiast „zasady”, o których mowa w art. 81 u.o.o.z. należy rozumieć jako ogólne i generalne postanowienia określające, komu mogą być udzielane dotacje, jakie czynności ma wykonać podmiot ubiegający się o dotację, aby mógł ją otrzymać, a także na jakie zadania może być udzielona dotacja. Zasady udzielania dotacji to także postępowanie $\mathrm{z}$ wnioskiem o udzielenie dotacji, wymagane dokumenty do rozpoznania wniosku oraz forma załatwienia wniosku. Krąg podmiotów mogących ubiegać się o dotację $\mathrm{z}$ budżetu jednostki samorządu terytorialnego na prowadzenie prac konserwatorskich, restauratorskich i robót budowlanych przy zabytku wpisanym do rejestru zabytków ogranicza się do osób fizycznych lub jednostki organizacyjnej posiadającej tytuł prawny do zabytku wynikający z prawa własności, użytkowania wieczystego, trwałego zarządu, ograniczonego prawa rzeczowego albo stosunku zobowiązaniowego. O udzieleniu dotacji konkretnemu podmiotowi oraz o jej wysokości wypowiada się wyłącznie organ stanowiący jednostki samorządu terytorialnego w odrębnej uchwale podjętej na podstawie uchwały określającej zasady udzielania dotacji na prace konserwatorskie, restauratorskie lub roboty budowlane przy zabytku wpisanym do rejestru. Udzielając dotacji celowej konkretnemu podmiotowi na prace przy zabytku, rada gminy musi działać zgodnie z uchwalonymi przez siebie zasadami udzielania dotacji na sfinansowanie prac przy zabyt-

17 Ustawa z dnia 27 sierpnia 2009 r. o finansach publicznych (Dz.U. z 2013 r., poz. 885 , ze zm.). 
ku wpisanym do rejestru zabytków (zob. uchwała RIO w Poznaniu z dnia 22 stycznia 2014 r., znak: 2/105/2014). Przepis kompetencyjny art. 81 ust. 1 u.o.z.z. odnosi się wprost jedynie do „zasad udzielania dotacji”, nie może zatem stanowić materialnoprawnej podstawy do przyjmowania, iż w zakresie tego pojęcia mieści się uprawnienie do określenia na przykład zawartości umowy dotacyjnej oraz prowadzenia kontroli realizacji zadania poprzez obowiązek złożenia sprawozdania i dokumentów związanych z realizacją dotowanego zadania, czy ustanawianie sposobu ewidencjonowania i upowszechniania informacji o udzielonych dotacjach (zob. uchwała RIO w Zielonej Górze z dnia 19 listopada 2013 r., znak: 362/2013). Nie można także, w drodze uchwały obligować Wojewódzkiego Konserwatora Zabytków do zatwierdzania kosztorysów prac, jakie mają być prowadzone przy zabytkach (zob. uchwała RIO w Poznaniu z dnia 22 kwietnia 2009 r., znak: 7/308/2009).

Dotacje przyznawane na podstawie art. 81 ust. 1 u.o.o.z., są dotacjami celowymi w rozumieniu u.f.p. i podlegają, określonemu w tej ustawie charakterystycznemu dla dotacji, reżimowi prawnemu w zakresie nie tylko swobody przyznawania i wypłaty dotacji, ale także w zakresie szczególnych zasad zwrotu dotacji do budżetu jednostki samorządu terytorialnego (zob. uchwała RIO w Zielonej Górze z dnia 20 maja 2009 r., znak: 116/2009). O ile cechą właściwą każdej dotacji jest jej „rozliczenie”, o tyle taka czynność nie obejmuje „kontroli na miejscu u beneficjenta” ani „w trakcie realizacji zadania", a tylko udokumentowanie przed organem dotującym faktu poniesienia wydatków związanych z tego rodzaju dotacją (zob. uchwała RIO w Krakowie z dnia 23 maja 2013 r., znak: KI-411/148/13).

Unormowanie zawarte w art. 81 u.o.o.z. odsyła do regulacji u.f.p., która nie zawiera postanowień odnośnie do sankcji utraty prawa do ubiegania się o dotację $\mathrm{z}$ budżetu jednostki samorządu terytorialnego na kolejne trzy lata. W związku z powyższym rada gminy nie ma umocowania prawnego do ustanowienia w swojej uchwale sankcji nieprzewidzianej w przepisach u.f.p. (zob. uchwała RIO w Warszawie z dnia 28 kwietnia 2011 r., znak: $150 / K / 11$ ). Ponadto postępowanie w sprawie udzielenia dotacji celowej $\mathrm{z}$ budżetu gminy na prace konserwatorskie, restauratorskie lub roboty budowlane przy zabytku wpisanym do rejestru prowadzone jest na podstawie uchwały podjętej na podstawie u.o.o.z., a nie na podstawie tej ustawy, co przesądza o braku odpowiedzialności karnej z art. $233 \$ 1$ k.k.18 (zob. uchwała RIO w Rzeszowie z dnia 10 stycznia 2012 r., znak: I/19/2012).

Nie jest także dopuszczane ograniczenie lub rozszerzenie zakresu dotowanych prac przy zabytku, w stosunku do katalogu określonego w art. 77 u.o.o.z. Ujęty w art. 77 u.o.o.z. katalog nakładów koniecznych, na jakie

18 Ustawa z dnia 6 czerwca 1997 r. Kodeks karny (Dz.U. z 1997 r., Nr 88, poz. 553, ze zm.). 
może być przeznaczona dotacja $\mathrm{z}$ budżetu jednostki samorządu terytorialnego, ma zamknięty charakter i nie może być rozszerzony o inne nakłady konieczne (uchwały RIO: w Lublinie z dnia 6 maja 2014 r., znak: 85/2014 oraz z dnia 24 kwietnia 2012 r., znak: 38/2012; we Wrocławiu z dnia 11 kwietnia 2012 r., znak: 37/2012). W konsekwencji wykonanie instalacji oświetlenia kościołów nie zalicza się do prac konserwatorskich, które mogą być dofinansowane przez gminy na podstawie u.o.o.z. (zob. uchwała RIO w Katowicach z dnia 31 lipca 2008 r., znak: 75/XVIII/08). Również rozszerzenie $\mathrm{w}$ uchwale rady miasta zakresu prac objętych dotacją z budżetu jednostki samorządu terytorialnego na „badania archeologiczne" wykracza poza upoważnienie ustawowe określone w art. 81 u.o.o.z. (zob. wyrok WSA w Krakowie z dnia 25 stycznia 2011 r., sygn. akt I SA/Kr 1673/10, LEX nr 749225).

Podobnie jakakolwiek próba modyfikowania pojęcia zabytku w uchwale organu stanowiącego jest niedozwolona i stanowi istotne naruszenie wskazanego wyżej przepisu. Dla przykładu jako niedopuszczalne można wskazać ograniczenie przedmiotu dotowania do nieruchomości (z wyłączeniem ruchomości) wpisanych do rejestru zabytków ${ }^{19}$. Niemniej należy zgodzić się z tezą, że dotowane mogą być jedynie prace przy zabytku rejestrowym (zob. uchwała RIO w Kielcach z dnia 26 października 2011 r., znak: 74/2011 oraz uchwała RIO w Opolu z dnia 1 grudnia 2010 r., znak: 26/70/2010).

Udzielenie dotacji, o której mowa w art. 81 u.o.o.z., nie może być uzależnione od ilości wykonanych już w poprzednich latach prac konserwatorskich, restauratorskich lub robót budowlanych przy danym zabytku czy wskazania innych źródeł finansowania prac lub robót budowlanych przy zabytku. Wniosek winien być rozpatrywany w oparciu o aktualne potrzeby związane z zapewnieniem ochrony substancji zabytkowej (zob. uchwała RIO w Krakowie z dnia 2 listopada 2011 r., znak: KI-411/485/11).

Rola samorządu terytorialnego w ochronie dziedzictwa kulturowego jest współcześnie bardzo doniosła, choć nie zawsze należycie zidentyfikowana. Efektywne wykonywanie wskazanych zadań własnych ma nie tylko istotne znaczenie dla zachowania zasobu zabytkowego, ale również korzystnie wpływa na rozwój lokalny, integrację społeczności, pobudzając wzrost ruchu turystycznego, a w konsekwencji rozwój gospodarczy i tworzenie nowych miejsc pracy. Ponadto jednostki samorządu terytorialnego są również, zgodnie ze statystykami prowadzonymi przez Krajowy Ośrodek Badań i Dokumentacji Zabytków, właścicielem ok. 20\% zabytków nieruchomych i w związku z tym są zobowiązane do ich zacho-

19 K. Sawicka, Wydatki z budżetu gminy w formie dotacji. Zagadnienia prawnofinansowe, „Przegląd Prawa i Administracji” 2009, nr 80, s. 151-173. 
wania w należytym stanie. Obowiązek opieki obciążający właścicieli to: naukowe badanie i dokumentowanie zabytków, prowadzenie wymaganych prac konserwatorskich, restauratorskich i robót budowlanych przy zabytku, zabezpieczenie i utrzymanie zabytku oraz jego otoczenia w jak najlepszym stanie; korzystanie z zabytku w sposób zapewniający trwałe zachowanie jego wartości; popularyzowanie i upowszechnianie wiedzy o zabytku oraz jego znaczeniu dla historii i kultury (art. 5 u.o.o.z.). Zadania własne poszczególnych jednostek samorządu terytorialnego, odnoszące się do zachowania dziedzictwa kulturowego, należy więc postrzegać niezmiernie szeroko, a więc również z perspektywy gminy, powiatu i województwa jako właścicieli zabytków ${ }^{20}$.

Poważnym wyzwaniem państwa jest więc wspieranie samorządu terytorialnego na rzecz zwiększenia jego poziomu zaangażowania $\mathrm{w}$ realizację zadań na rzecz ochrony zabytków. Dążenie do tworzenia zdecentralizowanych i dostosowanych do lokalnych potrzeb i uwarunkowań programów opieki nad zabytkami, wdrażanych przez jednostki samorządu terytorialnego poszczególnych szczebli stanowi zresztą jedną z dyrektyw Krajowego programu Opieki nad Zabytkami na lata 2014-2017 przyjętego przez Radę Ministrów (uchwała Rady Ministrów nr 125/2014 z dnia 24 czerwca 2014 r. w sprawie „Krajowego programu ochrony zabytków i opieki nad zabytkami"). Cel ten nie zostanie jednak osiągnięty w sytuacji, gdy stosowanie instrumentów prawnych zapewniających zaangażowanie jednostek samorządu terytorialnego w opiekę nad zabytkami napotyka problemy natury legislacyjnej. Szczególnie niepokojące są nieprawidłowości dotyczące realizacji kompetencji uchwałodawczej w przedmiocie udzielania dotacji na prace przy zabytku. Należy wskazać, że przyznanie dotacji ( $w$ formie umowy) stanowi kompetencję organów administracji publicznej i decyzja $\mathrm{w}$ tym zakresie (pozytywna lub negatywna) nie może być przedmiotem kontroli sądowoadministracyjnej. Brak jest bowiem przepisów prawa, które dawałyby sądowi podstawę do wyprowadzania tezy o konieczności rozstrzygania w sprawie odmowy przyznania dotacji na konserwacje i remonty zabytków w drodze decyzji administracyjnej - przyjęcie takiej tezy opierałoby się na wykładni contra legem przepisu art. 75 u.o.o.z. (zob. postanowienie NSA z dnia 29 listopada 2007 r., sygn. akt II GSK 210/07, LEX nr 494049).

Trudno przy tym wskazać na określony cel, któremu miałoby sprzyjać przekraczanie delegacji ustawowych. Praktyka związana ze stosowaniem art. 36 u.o.o.z. wskazuje na chęć rozszerzenia wynikającego z ustawy zakresu ochrony zabytków. Brak jest jednak w tych działaniach konsekwencji i szerszej perspektywy. Jest to szczególnie widoczne w kontekście nikłego zainteresowania uchwalaniem lokalnych programów opieki nad zabyt-

20 K. Zalasińska, op. cit. 
kami ${ }^{21}$, czy możliwością objęcia ochroną krajobrazu kulturowego. Mimo upływu ponad 10 lat od wejścia w życie przepisów przewidujących ten instrument ochrony zabytków, do tej pory powołano jedynie 27 parków kulturowych.

Natomiast problemy rysujące się na tle funkcjonowania art. 81 u.o.o.z. wskazują na dążenie rad gmin do ograniczania możliwości ubiegania się o dotacje na opiekę nad zabytkami. Jedynym oczywistym powodem wprowadzania dodatkowych restrykcji i obostrzeń na poziomie legislacji administracyjnej w tym zakresie zdają się być względy finansowe (ograniczony budżet jednostek samorządu terytorialnego).

\section{Bibliografia}

Komentarz do ustawy o samorzqdzie województwa, red. Bandarzewski K., Dąbek D., Dobosz P. et al., Warszawa 2005.

Prawo administracyjne: pojęcia, instytucje, zasady w teorii i orzecznictwie, red. Duniewska Z., Jaworska-Dębska B., Michalska-Badziak R. et al., Warszawa 2009.

Konstytucja Rzeczypospolitej Polskiej. Komentarz, red. Haczkowska M., Warszawa 2014.

Izdebski H., Samorzad terytorialny. Podstawy ustroju i działalności, Warszawa 2011.

Kmieciak Z., Stahl M., Akty nadzoru nad działalnościq samorządu terytorialnego, „Samorząd Terytorialny” 2001, nr 1-2.
Rymer M., Rola jednostek samorządu terytorialnego w systemie ochrony zabytków - analiza wybranych problemów [w:] Ochrona zabytków militarnych Helu, red. Gryszczyńska A., Konieczna B., Toruń 2006.

Sawicka K., Wydatki z budżetu gminy $w$ formie dotacji. Zagadnienia prawnofinansowe, „Przegląd Prawa i Administracji” 2009, nr 80.

Zalasińska K., Ochrona dziedzictwa kulturowego jako zadanie wtasne jednostek samorzadu terytorialnego, http://www.samorzad.lex.pl/czytaj/-/artykul/ochrona-dziedzictwa-kulturowego-jako-zadanie-wlasne -jednostek-samorzadu-terytorialnego (dostęp 19.09.2015).

21 Można prześledzić stopniowy wzrost liczby tych dokumentów, choć nadal większość gmin nie wywiązała się z obowiązku ich przyjęcia. Najwolniej postępuje proces tworzenia powiatowych programów opieki nad zabytkami - obecnie obowiązuje ich zaledwie 47 (12,4\% wszystkich powiatów), w większości województw obowiązują 2-3 powiatowe programy, najwięcej w województwach mazowieckim - 7 - i warmińsko-mazurskim - 6 programów. W odniesieniu do wojewódzkich programów opieki nad zabytkami, stanowiących ważne dokumenty strategiczne w regionie, należy zauważyć, że na koniec kwietnia 2014 r. trzy województwa nie posiadały aktualnego wojewódzkiego programu opieki nad zabytkami - dolnośląskie, małopolskie i podlaskie. (zob. uchwała Rady Ministrów nr 125/2014 z dnia 24 czerwca 2014 r. w sprawie „Krajowego programu ochrony zabytków i opieki nad zabytkami", s. 25 i nast.). 


\section{Orzecznictwo}

- Postanowienie NSA z dnia 29 listopada 2007 r., sygn. akt II GSK 210/07, LEX nr 494049.

- Rozstrzygnięcie nadzorcze Wojewody Dolnośląskiego z dnia 14 czerwca 2012 r., znak: NK-N13.4131.388.2012.JT1.

- Rozstrzygnięcie nadzorcze Wojewody Dolnośląskiego z dnia 27 lipca 2012 r., znak: NK-N5.4131.652.2012.GD1.

- Rozstrzygnięcie nadzorcze Wojewody Dolnośląskiego z dnia 29 lipca 2011 r., znak: NK-N.4131.713.2011.JT1-1.

- Rozstrzygnięcie nadzorcze Wojewody Kujawsko-Pomorskiego z dnia 17 marca 2014 r., znak: 15/14.

- Rozstrzygnięcie nadzorcze Wojewody Podlaskiego z dnia 29 kwietnia 2008 r., znak: NK.II.DJ.0911-94/08.

Uchwała RIO w Gdańsku z dnia 2 października 2014 r., znak: 199/G127/D/14.

Uchwała RIO w Katowicach z dnia 31 lipca 2008 r., znak: 75/XVIII/08.

Uchwała RIO w Kielcach z dnia 26 października 2011 r., znak: 74/2011.

Uchwała RIO w Kielcach z dnia 3 sierpnia 2011 r., znak: 64/2011.

Uchwała RIO w Kielcach z dnia 4 stycznia 2012 r., znak: 1/2012.

Uchwała RIO w Krakowie z dnia 23 maja 2013 r., znak: KI-411/148/13.

Uchwała RIO w Lublinie z dnia 24 kwietnia 2012 r., znak: 38/2012.

Uchwała RIO w Lublinie z dnia 6 maja 2014 r., znak: 85/2014.

Uchwała RIO w Łodzi z dnia 29 czerwca 2010 r., znak: 23/105/2010.

Uchwała RIO w Opolu z dnia 1 grudnia 2010 r., znak: 26/70/2010.

Uchwała RIO w Poznaniu z dnia 12 października 2011 r., znak: 20/1652/2011.

Uchwała RIO w Poznaniu z dnia 12 stycznia 2011r., znak:1/30/2011.

Uchwała RIO w Poznaniu z dnia 22 kwietnia 2009 r., znak: 7/308/2009.

Uchwała RIO w Poznaniu z dnia 22 stycznia 2014 r., znak: 2/105/2014.

Uchwała RIO w Rzeszowie z dnia 10 stycznia 2012 r., znak: I/19/2012.

Uchwała RIO w Rzeszowie z dnia 2 czerwca 2009 r., znak: XII/3803/09.

Uchwała RIO w Rzeszowie z dnia 3 kwietnia 2012 r., znak: VII/1473/2012.

Uchwała RIO w Rzeszowie z dnia 5 maja 2009 r., znak: X/2936/2009.

Uchwała RIO w Szczecinie z dnia 17 listopada 2010 r., znak: XXVII/157/S/2010.

Uchwała RIO w Warszawie z dnia 28 kwietnia 2011 r., znak: 150/K/11.

Uchwała RIO w Zielonej Górze z dnia 19 listopada 2013 r., znak: 362/2013.

Uchwała RIO w Zielonej Górze z dnia 20 maja 2009 r., znak: 116/2009.

Uchwała RIO w Zielonej Górze z dnia 27 listopada 2009 r., znak: 225/2009.

Uchwała RIO w Krakowie z dnia 2 listopada 2011 r., znak: KI-411/485/11. 